\title{
WŁADYSŁAW ROZWADOWSKI
}

\section{O NABYCIU UŻYTKOWANIA WIECZYSTEGO W DRODZE ZASIEDZENIA UWAGI KRYTYCZNE*}

Problematyka użytkowania wieczystego ${ }^{1}$ od kilkudziesięciu lat stanowi przedmiot żywego zainteresowania w literaturze prawniczej i bogatym orzecznictwie sądowym. Mimo to wiele związanych z tym kwestii pozostaje nadal kontrowersyjnych. Szczególnie sporna sprawą pozostaje kwestia możliwości zasiedzenia prawa użytkowania wieczystego. Nie brakuje też stwierdzenia, że możliwość taka „budzi wątpliwości”2. Kluczowy w tym względzie jest zakres możliwej do zastosowania analogii przepisów o prawie własności do użytkowania wieczystego i charakter prawny użytkowania wieczystego. Pojawia się bowiem pytanie, czy użytkowanie wieczyste należy traktować jako zwykłe prawo pochodne wobec prawa własności czy też szczególnego rodzaju prawo rzeczowe, do którego w szerokim zakresie należy stosować przepisy o własności nieruchomości, i jaki wpływ ma przyjęcie któregokolwiek ze stanowisk na możliwość stosowania przepisów o pierwotnym sposobie nabycia prawa, jakim jest zasiedzenie.

Zanim jednak skoncentrujemy się na szczegółowych rozważaniach, spróbujmy na wstępie przyjrzeć się bliżej samej instytucji zasiedzenia.

$$
* * *
$$

Zasiedzenie po raz pierwszy pojawiło się w prawie rzymskim i nieznane było $\mathrm{w}$ żadnym innym państwie antycznym ${ }^{3}$. Należy przy tym do najstarszych instytucji prawa rzymskiego. Jego zasady sformułowane zostały bowiem po raz pierwszy w ustawie XII tablic ${ }^{4}$, w której, w tablicy VI, czytamy: „usus auctoritas fundi bienium est [...] ceterarum rerum omnium annus est usus"

\footnotetext{
* Autor pragnie serdecznie podziękować doktorowi Grzegorzowi Kuczyńskiemu za uwagi poczynione przed oddaniem publikacji do druku.

${ }^{1}$ Użytkowanie wieczyste wprowadziła w $1961 \mathrm{r}$. ustawa o gospodarce terenami w miastach i osiedlach, w dniu 14 lipca tegoż roku (Dz. U. Nr 32, poz. 159) kilka razy zmieniana (t.jedn.: z 7 lipca 1969 r., Dz. U. Nr 22, poz. 159; dalej jako: użytk.wiecz.).

${ }^{2}$ Z. Truszkiewicz, w: System prawa prywatnego, t. 4, Warszawa 2012, s. 77.

${ }^{3}$ E. Volterra, Istituzioni di diritto romano, Roma 1972, s. 345; M. Talamanca, Istituzioni di diritto romano, Milano 1990, s. 420.

${ }^{4}$ Ustawa ta uchwalona została w latach 451 i 450 przed Chr. jako pierwsza w rzymskim porządku prawnym.

${ }^{5}$ Cicero, Topica 4, 23: „Gwarancja (spokojnego) posiadania nieruchomości trwa dwa lata, posiadania wszystkich pozostałych rzeczy - jeden rok".
} 
Ustawa XII tablic była spisem prawa zwyczajowego, możemy zatem przyjąć, że zasiedzenie było już znane przed jej uchwaleniem. Z cytowanego przypisu wynika, że istniały trzy wymogi zasiedzenia: rzecz musiała nadawać się do nabycia na niej prawa (res habilis) ${ }^{6}$, jej posiadanie (usus), później zastąpione terminem possessio, wreszcie upływ czasu tego posiadania (tempus). Do wymogów tych w okresie późniejszym, prawdopodobnie z początkiem okresu klasycznego ${ }^{7}$, dodano kolejne dwa wymogi: słuszny tytuł prawny (iustus titulus) oraz dobrą wiarę (bona fides), która istnieć musiała jedynie w momencie nabycia posiadania. Te wymogi przetrwały w prawie rzymskim aż do czasów justyniańskich.

Co się tyczy wymogów posiadania, to zasadniczo chodziło wyłącznie o posiadanie właścicielskie, obejmujące faktyczne władanie rzeczą (corpus) oraz zamiar zachowania jej dla siebie (animus). Przedmiotem posiadania w Rzymie mogły być tylko rzeczy materialne ${ }^{8}$. Nie było natomiast znane posiadanie rzeczy niematerialnych, do których należały zwłaszcza prawa majatkowe $^{9}$. Koncepcja posiadania prawa pojawiła się w Rzymie dopiero w okresie tzw. wulgaryzacji prawa ${ }^{10}$, który przypada na IV-VI w., od rządów Konstantyna do Justyniana. W przedmiotowym okresie dokonywano znacznych uproszczeń prawa, częstokroć na tyle głębokich, że odstępowano od jego fundamentów. Najczęściej przyczyną wulgaryzacji prawa było po prostu jego niezrozumienie ${ }^{11}$. Tak ukształtowana koncepcja posiadania prawa przyjęta została w części nowożytnych kodeksów prawa cywilnego i funkcjonuje po dziśs dzień w niektórych systemach prawnych. Rozwój instytucji zasiedzenia trwający w Rzymie ponad 1000 lat zakończył Justynian. Wydłużył on okres zasiedzenia nieruchomości do lat 10 między mieszkańcami tej samej prowincji lub 20 między mieszkańcami różnych prowincji. Ostatecznie wypracowany przez Rzymian model instytucji zasiedzenia, z niewielkimi zmianami, funkcjonuje po dziś dzień w wielu systemach prawa cywilnego, jako jeden z podstawowych sposobów nabycia prawa własności.

\footnotetext{
${ }^{6} \mathrm{~Np} . \mathrm{z}$ mocy tej ustawy niedopuszczalne było np. zasiedzenie rzeczy pochodzących z kradzieży (res furtivae).

${ }^{7}$ Okres ten obejmował lata 27 przed Chr. - 235 po Chr. Owych pięć wymogów w okresie średniowiecza ujęto w znanych heksametr: „res habilis, titulus, fides, possessio, tempus”. Zob. D. Stojčevic, A. Romae, Dicta et regulae iuris, Beograd 1971, s. 442.

${ }^{8}$ Digesta 41, 2, 3, pr. (Paulus): „Possideri autem possunt, quae sund corporalia” (,posiadać zaś można tylko rzeczy materialne”).

${ }^{9}$ Digesta 41, 3, 1, 4, 36 (Paulus): „Non possideri intellegitur ius incorporale” („nie można sobie wyobrazić posiadania rzeczy niematerialnej”). Jedyny wyjątek stanowiło tam posiadanie służebności i posiadanie prawa do spadku. To pierwsze zniosła lex Scribonia prawdopodobnie z roku 50 przed Chr. (G. Rotondi, Leges publicae populi Romani, Hildesheim 1962, s. 414). To drugie odnoszące się wyłącznie do spadku leżącego (hereditas iacens) zmieniło się już w późnej republice na normalne zasiedzenie przedmiotów spadkowych.

${ }_{10}$ Termin „vulgaris” oznacza „zwyczajny, normalny, ludowy, pospolity”.

${ }^{11}$ Szerzej na temat prawa wulgarnego zob. W. Osuchowski, Zarys rzymskiego prawa prywatnego, Warszawa 1971, s. 94 i n.; K. Kolańczyk, Prawo rzymskie, Warszawa 1978, s. 76 i n.
} 


\section{$* * *$}

W tym miejscu należy poczynić kilka uwag dotyczących tego, jak przedstawiała się problematyka możliwości zasiedzenia użytk. wiecz. w świetle Dekretu o prawie rzeczowym z 1946 r. przed wejściem w życie Kodeksu cywilnego. Prawo użytkowania wieczystego zastapiło funkcjonujaca w okresie powojennym „własność czasową”. Ustawa z 14 lipca 1961 r., wprowadzając użytk. wiecz., nie określiła charakteru tego prawa, a ponieważ weszła w życie pod rządami Prawa rzeczowego ${ }^{12}$, w nauce, jak i w orzecznictwie, traktowano je jako należące do ograniczonych praw rzeczowych, ujętych w tytule IV-X Prawa rzeczowego, z uwagi na to, iż było prawem na rzeczy cudzej (ius in re aliena). Przy takim założeniu zarówno judykatura, jak i doktryna ${ }^{13}$ dopuszczały możliwość zasiedzenia użytk. wiecz. z mocy art. 127 i 296 Dekretu $^{14}$. Było to dopuszczalne, gdyż Dekret, w sposób wyraźny, przewidywał możliwość posiadania nie tylko rzeczy materialnych, ale również praw. Artykuł 127 stanowił wyraźną podstawę ustawową nabycia praw ujawnionych w księdze wieczystej w drodze zasiedzenia. Jedna z przesłanek było m.in. posiadania w dobrej wierze prawa przez okres 10 lat. W świetle zaś art. 296 Dekretu o prawie rzeczowym użytkownik wieczysty był posiadaczem prawa, którego treści odpowiadała władza nad rzeczą użytkownika.

Jak już wspomniano, koncepcja posiadania prawa pojawiła się w prawie rzymskim w okresie poklasycznym, tzw. wulgaryzacji prawa. Do Dekretu o prawie rzeczowym przejęta została z kodeksu austriackiego (ABGB - Patent cesarski z 1 czerwca 1811 r. nr 946), w którym w art. 311 czytamy: „wszelkie rzeczy zmysłowe i niezmysłowe, będące przedmiotem obrotu prawnego można wziąć w posiadanie”. ABGB obowiązywał, jak wiadomo, na terenie byłego zaboru austriackiego do wydania Dekretu o prawie rzeczowym, czyli do końca roku 1946. Dekret o prawie rzeczowym był przygotowany w okresie międzywojennym, a głównym jego autorem był Fryderyk Zoll (Junior), profesor Uniwersytetu Jagiellońskiego. Stąd zapewne z jego inicjatywy do Dekretu o prawie rzeczowym przyjęto austriacką koncepcję posiadania prawa.

$$
* * *
$$

Przejdźmy teraz do problemu, który jest przedmiotem naszego szczególnego zainteresowania w niniejszym opracowaniu: możliwości nabycia, w świetle Kodeksu cywilnego użytk. wiecz. w drodze zasiedzenia. Użytk. wiecz. do polskiego porządku prawnego wprowadzono, jak już wiemy, ustawą z 14 lipca 1961 r. Mimo że od tej legislacji upłynęło już 56 lat, w kwestiach dotyczaccych tego prawa istnieje wiele poważnych kontrowersji ${ }^{15}$. Najważniejsze z nich do-

12 Dekret z 11 października 1946 r. - Prawo rzeczowe (Dz. U. Nr 57, poz. 319).

${ }^{13} \mathrm{O}$ możliwości nabycia użytkowania wieczystego w drodze zasiedzenia przed wprowadzeniem kodeksu cywilnego zob. S. Breyer, Prawo wieczystego użytkowania, „Państwo i Prawo” 17, 1962, z. 8-9, s. 313 i 320; A. Kunicki, Zasiedzenie w prawie polskim, Warszawa 1964, s. 47.

${ }^{14}$ M. Majerowicz, w: J. Ignatowicz (red.), Kodeks cywilny, Warszawa 1972, s. 661.

15 Już w roku 1977 S. Wójcik (Z problematyki użytkowania wieczystego, „Nowe Prawo” 1977, nr 6) pisał: „od kilkunastu lat użytkowanie wieczyste stanowi przedmiot żywego, niesłabnącego zainteresowania zarówno Sądu Najwyższego jak i piśmiennictwa prawniczego”. 
tyczą trzech problemów: charakteru prawnego wieczystego użytkowania, charakteru prawnego posiadania $\mathrm{w}$ ramach wieczystego użytkowania, wreszcie możliwość jego nabycia w drodze zasiedzenia.

$\mathrm{W}$ kwestii pierwszej istnieja dwa przeciwstawne sobie poglądy. Według jednego z nich użytk. wiecz. jest ograniczonym prawem rzeczowym ${ }^{16}$, według drugiego zaś poglądu, który zdecydowanie przeważa zarówno w orzecznictwie, jak i literaturze - użytk. wiecz. jest prawem pośrednim między prawem własności a ograniczonym prawem rzeczowym, przy czym bardziej zbliżone jest do własności aniżeli do ograniczonych praw rzeczowych ${ }^{17}$. Za tym poglądem przemawiać ma umieszczenie w Kodeksie cywilnym użytk. wiecz. w odrębnym tytule (II) księgi drugiej tegoż Kodeksu zatytułowanej „Własność i inne prawa rzeczowe"18. I tu wyłania się pytanie zasadnicze: jaka cecha danego prawa ma znaczenie dla określenia jego charakteru. Otóż, generalnie, cechą zasadniczą jest nie lokalizacja danego przepisu w akcie normatywnym, lecz jego treść. Tak więc umiejscowienie przepisu w danym akcie normatywnym, bądź w danej części aktu normatywnego, nie może determinować w sposób bezwzględny jego charakteru prawnego ${ }^{19}$.

Z tego punktu widzenia treści poszczególnych praw rzeczowych w każdym systemie prawa rzeczowego istnieje podział tychże praw na dwie kategorie, które tak dalece różnią się od siebie, że nawzajem się wykluczają. Prawa te są albo pełne albo ograniczone. Tertium non datur. Możemy zatem pomiędzy prawem rzeczowym ograniczonym a prawem na rzeczy cudzej postawić spokojnie znak równości. Jeżeli prawo rzeczowe nie jest prawem pełnym, to może być tylko prawem rzeczowym ograniczonym. Pełnym prawem rzeczowym jest wyłącznie prawo własności, wszystkie pozostałe prawa rzeczowe należą do kategorii praw ograniczonych. Każde z nich nie ma bowiem bytu samoistnego, autonomicznego, lecz bazuje na prawie cudzej własności, zawiera treść jakiegoś fragmentu praw własności, które w normalnych warunkach przysługuje wyłącznie właścicielowi. Z tego tytułu prawa te określa się mianem praw na rzeczy cudzej (iura in re aliena) ${ }^{20}$. Innymi słowy, ograniczone prawo rzeczo-

${ }^{16}$ J. Winiarz, Użytkowanie wieczyste, Warszawa 1967, s. 178 i n.; J. Paliwoda, Recenzja z pracy Winiarza, „Nowe Prawo” 1968, nr 5, s. 827; A. Kopff, Charakter prawny wieczystego uzytkowania, „Studia Cywilistyczne” 9, 1967, s. 35 i n.; J. Ignatowicz, System prawa prywatnego, WrocławWarszawa-Kraków-Gdańsk 1977, s. 554; H. Witczak, Charakter prawny użytkowania wieczystego, „Przegląd Sądowy” 2001, nr 11-12, s. 50 i 63.

${ }_{17}$ Po raz pierwszy pogląd ten wyrażony został w uwagach do projektu kodeksu cywilnego z 1962 r.: „dostosowując do nowych warunków kształtuje się użytkowanie wieczyste jako instytucję pośrednią między kategorią własności, a kategorią ograniczonych praw rzeczowych”. Zob. na ten temat S. Wójcik, op. cit., s. 809 z obszerną literaturą i orzecznictwem Sądu Najwyższego w przyp. 14 .

${ }_{18}$ Jest to jedyny argument, za jakim opowiada się zarówno literatura, jak i orzecznictwo.

${ }^{19}$ Pogląd ten ma przecież swoje ogólne uzasadnienie w systemie prawnym. Przykładowo, na próbie determinowania charakteru prawnego przepisów prawnych, w regulacji procedury cywilnej można z powodzeniem odnaleźć przepisy o charakterze stricte materialnoprawnym, np. art. 189 i 320 KPC. Samo ich umieszczenie w regulacji KPC nie czyni ich przecież przepisami wyłącznie proceduralnymi, pozbawionymi materialnoprawnego charakteru. Liczy się treść danego przepisu, a nie jego umiejscowienie.

${ }^{20}$ Z. Nowakowski, Prawo rzeczowe, Warszawa 1969, s. 149. 
we jest prawem pochodnym wobec prawa własności, jako prawa pierwotnego. Powyższy pogląd uzasadniony był również przed wprowadzeniem Kodeksu cywilnego. O ograniczonych prawach rzeczowych Dekret traktował w tytułach IV-IX. Ponieważ akt ten nie zawierał przepisu odpowiadającego treści art. 244 k.c., po wprowadzeniu do porządku prawnego użytk. wiecz. traktowano je jako prawo rzeczowe ograniczone. Z mocy ówczesnego prawa ograniczone prawo rzeczowe, jeśli było wpisane do księgi wieczystej, mogło być nabyte w drodze zasiedzenia ${ }^{21}$. Po wprowadzeniu Kodeksu cywilnego, który wykluczył, co do zasady, możliwość zasiedzenia ograniczonego prawa rzeczowego ${ }^{22}$, w praktyce sądowej powstała wątpliwość, czy można zasiedzieć użytk. wiecz., zwłaszcza że Kodeks cywilny zarzucił koncepcję posiadania prawa ${ }^{23}$. Niektórzy autorzy możliwość taką dopuszczali ${ }^{24}$. W związku z tymi wątpliwościami prezes Sądu Najwyższego 17 lipca 1971 r. wystapił z wnioskiem o podjęcie przez Są Najwyższy uchwały co do nabycia użytk. wiecz. w drodze zasiedzenia. W dniu 11 grudnia 1975 r. ${ }^{25}$ Sąd Najwyższy podjął uchwałę, że Kodeks cywilny możliwość taką dopuszcza. Ponieważ Sąd Najwyższy postanowił wpisać uchwałę do księgi zasad prawnych, uzyskała ona moc wiążącą wobec tego sądu. Odtąd w orzeczeniach Sądu Najwyższego, a także w doktrynie, pogląd o możliwości nabycia użytk. wiecz. przez zasiedzenie stał się poglądem niemal powszechnym (communis opinio). Tylko nieliczni autorzy pogląd ten uważają za sporny.

Przyjrzyjmy się bliżej treści tej uchwały. Przyjmuje ona za aksjomat, że art. $244 \mathrm{KC}$ wprowadził wyczerpujące wyliczenie (numerus clausus) ograniczonych praw rzeczowych. Jak już wspomniano wyżej, o charakterze takiego prawa podmiotowego nie decyduje jego lokalizacja w akcie normatywnym, lecz jego treść. Jeżeli dotyczą one rzeczy cudzej i są skuteczne wobec każdego (erga omnes), odpowiadaja wymogom praw rzeczowych ograniczonych. Katalog praw wymienionych w art. $244 \mathrm{KC}$ nie jest katalogiem zamkniętym, charakter ograniczonych praw rzeczowych maja nadto inne prawa rzeczowe ${ }^{26}$. Bezwzględny charakter mają też niektóre prawa uregulowane w księdze III KC (art. $690 \mathrm{KC}$ i art. $910 \S 1 \mathrm{KC}$ ). Skoro istnieja na rzeczy i maja charakter bezwzględny, są bardzo zbliżone do ograniczonych praw rzeczowych.

Sąd Najwyższy, jeśli chciał zastosować w drodze analogii do użytk. wiecz. reguły dotyczace zasiedzenia, nie mógł przyjaćc, że prawo to jest ograniczonym prawem rzeczowym, gdyż wówczas, uzasadniając możliwość nabycia tego prawa droga zasiedzenia, musiałby konsekwentnie przyjąc za podstawę analogię nie z art. $172 \mathrm{KC}$, który dotyczy prawa własności, lecz z art. $292 \mathrm{KC}$, dotyczącego ograniczonych praw rzeczowych (konkretnie służebności), czemu sprzeciwiała się istotna zasada wykładni, że wobec przepisu wyjątkowego nie jest

21 Art. 127 Prawa rzeczowego.

${ }^{22}$ Z. Truszkiewicz, Posiadanie $w$ zakresie prawa użytkowania wieczystego, „Studia Iuridica Agraria” 5, 2005, s. 223. Inaczej E. Janeczko, Zasiedzenie, Warszawa 1981, s. 54.

23 Jedyny wyjątek stanowi art. $291 \mathrm{KC}$.

${ }_{24}$ S. Breyer, op. cit., s. 394; J. Goławska, Zbywanie, obciażanie $i$ wydzierżawianie nieruchomości państwowych, „Przegląd Ustawodawstwa Gospodarczego” 1962, nr 12, s. 392; A. Kunicki, op. cit., s. 46.

${ }^{25}$ III CZD 63/75.

${ }^{26}$ Katalog tych praw przedstawia S. Wójcik, op. cit., s. 81 i n., przyp. 17. 
dopuszczalna wykładnia rozszerzająca (exceptiones non sunt extendendae) ${ }^{27}$, a taki charakter ma niewatpliwie art. $292 \mathrm{KC}$.

Skoro Sąd Najwyższy w swojej uchwale z 11 grudnia 1975 r. zaprezentował pogląd, że użytk. wiecz., nie będąc ograniczonym prawem rzeczowym, jest odrębna „kategorią pośrednią między własnością a tym prawem” ${ }^{28}$, co było dla niego podstawowym argument za dopuszczalnością stosowania do użytk. wiecz. analogii z przepisów regulujących własność. Pragnąc zweryfikować tezę postawioną przez Sąd Najwyższy, przyjrzyjmy się zatem, jak wyglądają podobieństwa i różnice pomiędzy użytk. wiecz. a prawem własności ${ }^{29}$.

\section{Podobieństwa}

I. A. Własność jest prawem bezwzględnym. B. Użytk. wiecz. jest prawem bezwzględnym, ale taki charakter mają wszystkie prawa rzeczowe.

II. A. Własność wyłącza inne osoby od korzystania z niej (art. $140 \mathrm{KC}$ ). B. Użytk. wiecz. wyklucza inne osoby od korzystania z niej, ale taki charakter ma każde inne prawo podmiotowe ${ }^{30}$.

III. A. Właściciel ma prawo korzystać z rzeczy. B. Użytkownik wieczysty może korzystać z gruntu (art. $233 \mathrm{KC}$ ). Takie samo prawo przysługuje też zwykłemu użytkownikowi (art. $252 \mathrm{KC}$ ).

IV. A. Własność jest prawem zbywalnym i dziedzicznym. B. Użytk. wiecz. jest prawem zbywalnym i dziedzicznym, ale zbywalne jest też wiele innych praw podmiotowych.

V. A. Własność może być obciążona innymi prawami. B. Użytk. wiecz. może być obciążone innymi prawami, ale taką cechę mają też niektóre inne prawa rzeczowe.

VI. A. Umowa o przeniesienie własności nieruchomości winna być sporządzona w formie aktu notarialnego (art. $158 \mathrm{KC}$ ). B. Takiej samej formy wymaga umowa o przeniesienie użytk. wiecz. (art. $237 \mathrm{KC}$ ), ale takim samym wymogiem objęte jest np. przeniesienie spółdzielczego prawa do lokalu.

\section{Różnice}

I. A. Własność jest prawem rzeczowym pełnym, pierwotnym. B. Użytk. wiecz. jest prawem rzeczowym ograniczonym.

${ }^{27}$ A. Kunicki, op. cit., s. 74; Z. Radwański, Prawo cywilne, Warszawa 2009, s. 69; M. Zieliński, Wyktadnia prawa, Warszawa 2012, s. 243, z dalszą literatura w przyp. 18. Autor ten słusznie zauważa, że ta zasada interpretacji jest wielowiekowa, gdyż znana była już w prawie rzymskim: „exceptiones, quae personae cuique coherent non transeunt at alios” (Digesta 44, 1, 7, pr.: „wyjątki, które dotyczą jakiejś osoby, nie przechodzą na innych”); „exceptiones sunt strictissimae interpretationis” (SEC. Digesta 50, 17, 141, pr.: „wyjątki podlegają ścisłej interpretacji”). Por. też D. Stojčević, A. Romać, op. cit., s. 132.

${ }^{28}$ Zob. przyp. 17.

${ }^{29}$ Porównanie takie przeprowadzili już S. Breyer, op. cit., s. 313 i n.; A. Kunicki, op. cit., s. 44; T. Smyczyński, Charakter prawny wieczystego użytkowania, „Ruch Prawniczy, Ekonomiczny i Socjologiczny" 33, 1971, z. 1, s. 40.

${ }^{30}$ W. Rozwadowski, Koncepcje prawa własności w prawie polskim, w: O prawie i jego dziejach, Białystok-Katowice 2010, s. 1130. 
II. A. W myśl zasady superficies solo cedit wszystko, co na trwałe związane jest z gruntem, zawsze stanowi własność właściciela gruntu. B. Zasada superficies solo cedit nie ma pełnego zastosowania w użytk. wiecz., gdyż budynki znajdujące się na gruncie stanowią własność użytkownika, a nie właściciela gruntu.

III. A. Własność budynków i urządzeń na gruncie właściciela ma charakter trwały. B. Własność budynków i urządzeń gaśnie na gruncie użytkownika wieczystego wraz z wygaśnięciem jego prawa.

IV. A. Pożytki naturalne nieruchomości stanowią przez cały czas własność jej właściciela (art. $191 \mathrm{KC}$ ). B. Pożytki naturalne z gruntu w użytk. wiecz. stają się własnością użytkownika dopiero po ich odłączeniu od rzeczy macierzystej (art. $190 \mathrm{KC}$ ).

V. A. Prawo własności nie jest ograniczone w czasie, własność na rzeczy przysługuje zaś właścicielowi bądź do czasu przymusowego pozbawienia go tego prawa (np. wywłaszczenie, nacjonalizacja, sprzedaż egzekucyjna), bądź rozporządzenia rzeczą. Prawo własności nie może wygasnaćc. B. Użytk. wiecz. jest czasowo ograniczone (art. $236 \mathrm{KC}$ ), a użytkownik wieczysty może być tego prawa pozbawiony w każdym czasie za naruszenie postanowień umowy (art. 33 ust. 3 ustawy o gospodarce nieruchomościami w zw. z art. 240 KC). Użytk. wiecz. wygasa (art. 33 ust. 1 ustawy o gospodarce nieruchomościami).

VI. A. Prawo własności może istnieć na jakimkolwiek gruncie. B. Użytk. wiecz. może istnieć tylko na gruncie niektórych właścicieli (art. 232 KC).

VII. A. Przedmiotem prawa własności mogą być nieruchomości, a także rzeczy ruchome. B. Przedmiotem użytk. wiecz. mogą być tylko nieruchomości, i to niektóre.

VIII. A. Własność jest prawem na rzeczy własnej, jest prawem autonomicznym. B. Użytk. wiecz. jest prawem na rzeczy cudzej, nie jest prawem autonomicznym.

IX. A. Właściciel może być posiadaczem samoistnym rzeczy. B. Użytkownik wieczysty jest tylko posiadaczem zależnym, gdyż włada rzeczą cudza, a nie jak właściciel (art. $236 \mathrm{KC}$ ).

X. A. Właścicielowi nieruchomości przysługuje prawo do rozporządzania rzeczą (art. $140 \mathrm{KC)}$. B. Użytkownikowi wieczystemu przysługuje tylko prawo do rozporządzania przysługującym mu prawem (art. $233 \mathrm{KC}$ ).

XI. A. Treść prawa własności określona jest przepisami prawa. B. Treść użytk. wiecz., poza przepisami prawa, uregulowana być powinna także przez umowę zawarta z właścicielem gruntu.

XII. A. Przedmiotem regulacji prawa własności jest przede wszystkim prawo cywilne. B. Przedmiotem regulacji użytk. wiecz. jest poza prawem cywilnym także prawo administracyjne.

XIII. A. Właściciel z tytułu korzystania z gruntu nie płaci żadnego czynszu. B. Użytkownik wieczysty z tytułu korzystania z tego gruntu uiszcza właścicielowi opłatę roczną (art. $238 \mathrm{KC}$ ).

XIV. A. Kodeks cywilny zawiera szczegółowe regulacje dotyczące zasiedzenia nieruchomości (art. $172 \mathrm{KC}$ ). B. Kodeks cywilny nie zawiera wprost przepisów o nabyciu użyk. wiecz. w drodze zasiedzenia. 
XV. A. Własność ma wyłącznie charakter prawa bezwzględnego. B. Użytk. wiecz. ma zarówno charakter prawa bezwzględnego, jak i względnego. Jego ograniczenia wprowadzone umową ustanawiająca użytk. wiecz. mają charakter zobowiazaniowy ${ }^{31}$.

XVI. A. Właściciel może przenieść na drugiego posiadanie samoistne rzeczy bez przenoszenia nań prawa własności. B. Użytkownik wieczysty uczynić tego nie może, gdyż nie jest posiadaczem samoistnym rzeczy.

XVII. A. Własność nieruchomości nabywa się bez wpisu do księgi wieczystej. B. Prawo użytkowania wieczystego nabywa się dopiero po wpisie do księgi wieczystej.

XVIII. A. Właściciel może z rzeczą zrobić wszystko, z wyjątkiem tego, czego mu zabrania prawo. B. Użytk. wiecz. może z rzeczą zrobić tylko to, na co mu prawo pozwala.

Z powyższego porównania wynika, że cech wspólnych prawa własności i użytk. wiecz. jest niewiele. Ponadto wszystkie one sa charakterystyczne dla wielu innych praw rzeczowych ograniczonych. Różnic natomiast jest wiele. Trudno więc zaaprobować pogląd, że użytk. wiecz. jest bardziej zbliżone do własności aniżeli do ograniczonych praw rzeczowych ${ }^{32}$. W świetle powyższych uwag jest wręcz przeciwnie - użytk. wiecz. jest raczej bardziej zbliżone do zwykłego użytkowania aniżeli do prawa własności ${ }^{33}$. Różnice między tymi dwoma prawami sprowadzają się w zasadzie tylko do tego, że zwykłe użytkowanie jest niezbywalne, w drodze umowy może być zmodyfikowane tylko wyjątkowo (art. $253 \mathrm{KC}$ ), budynek wzniesiony na gruncie użytkowania stanowi własności właściciela gruntu, wreszcie krótszy jest czas trwania użytkowania zwykłego.

Zbyt daleko poszedł zatem Sąd Najwyższy, stosując analogię z art. 172 $\S 1 \mathrm{KC}$ do użytk. wiecz. Jakkolwiek analogia jest rodzajem prawodawstwa sadowego, ma jednak swoje granice. Nie może ona kreować instytucji nieznanej w polskim porządku prawnym. Jako że jednym z wymogów art. $172 \mathrm{KC}$ jest samoistne posiadanie rzeczy ${ }^{34}$, Są Najwyższy przyjmuje, na potrzeby uzasadnienia swojego poglądu, że użytkownik wieczysty jest „samoistnym posiadaczem prawa użytk. wiecz., które polega na wykonywaniu władztwa nad nieruchomością z wola posiadania jej dla siebie w zakresie odpowiadającym treści wieczystego użytkowania" ${ }^{35}$. Po pierwsze Kodeksowi cywilnemu obca jest, jak wspomniano, możliwość posiadania prawa. Jedyny wyjątek stanowi art. 352 $\S 1 \mathrm{KC}$ o posiadaniu służebności i nie określa się go jako posiadania samoistnego. Po drugie, jest to koncepcja trudna do zaakceptowania także $\mathrm{z}$ innych względów. Treść użytkowania wieczystego wyznacza umowa, a więc stosunek

31 J. Majorowicz, op. cit., s. 641; J. Winiarz, System prawa cywilnego, t. 2, Wrocław-Warszawa-Kraków-Gdańsk 1977, s. 553; S. Rudnicki, Charakter prawny użytkowania wieczystego, „Nowe Prawo” 1970, nr 12, s. 1775; H. Witczak, op. cit., s. 53 i 55.

${ }^{32}$ W ten sposób S. Rudnicki, op. cit., s. 1774.

${ }^{33}$ H. Witczak, op. cit., s. 59.

${ }^{34}$ Myli się M. Knotz (Powstanie prawa użytkowania wieczystego w wyniku zasiedzenia, „Monitor Prawniczy” 2014, nr 4, s. 222), twierdząc, że przesłanką zasiedzenia jest „posiadanie odpowiadające" treści prawa, które w wyniku zasiedzenia ma być nabyte.

${ }^{35}$ Wyrok SN z 17 kwietnia 1997 r., I CKU 32/97; wyrok SN z 28 września 2000 r., IV CKN $103 / 00$. 
obligacyjny, względny, istniejący pomiędzy właścicielem a użytkownikiem wieczystym i skuteczny między tymi stronami. Przyjęcie, iż można posiadać prawo w granicach m.in. treści umowy niewiążącej posiadacza, jest wątpliwa konstrukcja prawna.

W innych orzeczeniach termin „samoistne posiadanie prawa” Sąd Najwyższy zastapił fraza „,samoistne posiadanie nieruchomości”36. Polskie prawo cywilne dopuszcza, aby rzecz posiadało równocześnie kilka podmiotów - wyróżnia się bowiem posiadanie samoistne i posiadanie zależne. Samoistnym posiadaczem rzeczy może być jednak tylko jedna osoba ${ }^{37}$. Gdyby użytkownik wieczysty był posiadaczem samoistnym nieruchomości, po uchyleniu art. $177 \mathrm{KC}$ (28 lipca 1990 r.) nabyłby z mocy art. $172 \mathrm{KC}$ prawo własności, a nie użytk. wiecz. Jeśli posiadacz samoistny przenosi swoje władztwo na trzeciego, traci posiadanie samoistne. Traci je także wówczas, gdy zostanie mu ono odebrane czynem niedozwolonym (np. przez kradzież).

Właściciel, przekazując swą nieruchomość w użytk. wiecz., nie przestaje jednak być jej posiadaczem samoistnym. Zreszta jeśli użytkownik wieczysty włada nieruchomościa, jak to podkreśla Sąd Najwyższy, nie jak właściciel, to nie jest posiadaczem samoistnym, lecz zależnym. Jak wynika bowiem wprost z ustawowej definicji posiadania zależnego, jest to forma posiadania na podstawie określonego prawa, z którym wiąże się władztwo nad cudzą rzeczą. Posiadaniem zależnym jest zatem każde władztwo nad rzecza, jeżeli faktyczne jej władanie jest uzasadnione określonym stosunkiem prawnym pomiędzy właścicielem a posiadaczem zależnym.

W tym wypadku zatem, użytk. wiecz. jako prawo dające władztwo faktyczne nad cudzą rzeczą (Skarbu Państwa bądź jednostki samorządu terytorialnego), niczym nie różni się od użytkowania, najmu, dzierżawy, zastawu itd. To właśnie dlatego, że posiadanie rzeczy ma charakter zależny, nie dochodzi każdorazowo do zasiedzenia prawa własności nieruchomości przez użytkownika wieczystego (co jest oczywiste, skoro najdłuższy przewidziany w prawie okres zasiedzenia wynosi lat 30, najkrótszy zaś okres użytk. wiecz. lat 40). Nie można zatem mówić o jakimkolwiek samoistnym posiadaniu.

Należy zaznaczyć, że stosowanie analogii z prawa własności do użytk. wiecz. jest niewątpliwie dopuszczalne. Na przykład na tej podstawie trafnie przyjęto, że do ochrony użytk. wiecz. można stosować przepisy o ochronie własności, których Kodeks cywilny nie zawiera wprost. Tak samo dopuszczalne będzie zastosowanie analogii przepisów o współwłasności i odpowiednie ich stosowanie do użytk. wiecz. przysługującego większej liczbie osób.

Ustawodawca wcale jednak nie miał zamiaru umożliwiać użytkownikowi wieczystemu nabycie prawa $\mathrm{w}$ drodze zasiedzenia. $\mathrm{W}$ przeciwnym razie wprowadziłby do Kodeksu przepis następującej treści: „Użytk. wiecz. może być

${ }^{36}$ Wyrok SN z 25 marca 2004 r., II CK 105/03; wyrok SN z 23 lipca 2008 r., III CZP 68/08. Podobnie K. Górska, w: E. Gniewek, P. Machnikowski (red.), Kodeks cywilny. Komentarz, Warszawa 2016, s. 473; G. Wolak, Charakter prawny posiadania w zakresie prawa wieczystego użytkowania - ujęcie doktrynalne i orzecznictwo, „Monitor Prawniczy” 2011, nr 15, s. 812; A. Zbiegień-Turzańska, w: K. Osajda (red.), Kodeks cywilny. Komentarz, Warszawa 2013.

${ }_{37}$ Jeżeli osób jest więcej, każda z nich jest nie posiadaczem, lecz współposiadaczem (art. 206 KC), a ich udziały mogą być różne (art. 197 KC). 
nabyte przez zasiedzenie tylko w wypadku, gdy polega na wykonywaniu tego prawa już istniejącego. Przepisy prawa o nabyciu przez zasiedzenie stosuje się odpowiednio"38. Normę takiej treści mógł do Kodeksu cywilnego wprowadzić wyłącznie ustawodawca. Sąd tego uczynić nie mógł. Ustawodawca nie miał też potrzeby wprowadzania takiego przepisu, problemy wadliwego nabycia użytk. wiecz. rozwiąać bowiem można na podstawie prawa istniejącego, bez uciekania się do analogii z art. $172 \S 1 \mathrm{KC}$. W orzecznictwie i literaturze dostrzega się celowość zasiedzenia użytk. wiecz. w trzech przypadkach. Po pierwsze - gdyby okazało się, że umowa przenosząca to prawo dotknięta jest wadą nieważności, po drugie - gdy taka wadą dotknięta jest decyzja organu administracyjnego dopuszczajacca ustanowienie tego prawa bądź akt notarialny zawarty na podstawie takiej decyzji ${ }^{39}$, po trzecie - gdy postanowienie o stwierdzeniu nabycia spadku zostało wzruszone, a w spadku znajdowało się użytk. wiecz., z którego użytkownik korzystał nawet 20 czy 30 lat.

Ad 1. Jeśli nieważny był akt notarialny, z mocy którego nabywano użytk. wiecz., to nie było żadnej przeszkody, by sporządzić nowy akt notarialny (art. $237 \mathrm{KC}$ ). W razie trudności w uzyskaniu oświadczenia woli zbywcy tego prawa zastapić je można orzeczeniem sądu wydanym w trybie art. $64 \mathrm{KC}$.

Ad 2. Gdy nieważna była decyzja organu administracyjnego albo akt notarialny na podstawie tej decyzji zawarty, użytk. wiecz. w ogóle nie postawało $^{40}$. Do zasiedzenia nadaje się tylko prawo już istniejące. Tym wymogiem kierował się Sąd Najwyższy, ograniczając zasiedzenie użytk. wiecz. tylko, gdy zostało ono już ustanowione. Może również dojść do sytuacji, w której decyzja nie ma charakteru stricte konstytutywnego, lecz deklaratoryjno-konstytutywny, użytk. wiecz. zaś powstawało z mocy prawa (np. tzw. uwłaszczenie w trybie art. 200 ustawy o gospodarce nieruchomościami). W takim jednak przypadku nic nie stoi na przeszkodzie, aby ponownie wydać decyzję merytoryczna, po stwierdzeniu nieważności decyzji pierwotnej. Decyzja i tak wywoła skutki ex tunc (tj. stwierdza nabycie użytkowania wieczystego na dzień nabycia ipso iure - w przypadku „uwłaszczenia” 5 grudnia 1990 r.). W przypadku zaś, gdy wada nieważności decyzji wiąże się ściśle z brakiem zaistnienia przesłanek nabycia prawa (np. brak przesłanek „uwłaszczenia” w dniu 5 grudnia 1990 r. $)^{41}$, to oznacza to, że prawo to nigdy nie powstało z mocy ustawy na rzecz danego podmiotu. Ponownie więc nie może dojść do zasiedzenia prawa, które nie istnieje.

${ }^{38}$ W uchwale SN z 23 lipca 2008 r., III CZP 68/08, czytamy: „posiadanie w zakresie użytkowania samoistnego (wieczystego) nie można utożsamiać z posiadaniem jak właściciel. Konsekwentnie nie można dopuścić, aby posiadanie w zakresie użytkowania wieczystego zostało doliczone do okresu faktycznego wykonywania uprawnień właścicielskich".

${ }^{39}$ G. Wolak, op. cit., s. 816, proponuje w tej kwestii zmianę treści art. $336 \mathrm{KC}$, który powinien mieć brzmienie: „posiadaczem rzeczy jest zarówno ten, kto nią faktycznie włada jak właściciel, bądź wieczysty użytkownik (posiadacz samoistny) [...] taka redakcja art. $336 \mathrm{KC}$ sprzeciwia się koncepcji posiadania samoistnego przewidzianego w kodeksie cywilnym". Zob. na ten temat s. 76 .

${ }^{40}$ Inaczej Z. Truszkiewicz, Użytkowanie wieczyste. Zagadnienia konstrukcyjne, Kraków 2006, s. 491; idem, Posiadanie w zakresie..., s. 228.

${ }^{41}$ Przykładowo może chodzić o następcze stwierdzenie, że 5 grudnia 1990 r. nieruchomość nie została skutecznie oddana w zarząd państwowej osobie prawnej (np. wobec stwierdzenia nieważności decyzji o przekazaniu nieruchomości w zarząd). 
Ad 3. Od osoby, która nie jest spadkobierca, może dziedzic wymagać wydania użytk. wiecz. w drodze skargi windykacyjnej (art. 1029 KC). Takie prawo by spadkobiercy nie przysługiwało, gdyby użytkownik dokonał zasiedzenia użytk. wiecz.

W świetle powyższego pogląd Sądu Najwyższego, że co do możliwości nabycia przez zasiedzenie prawa wieczystego użytkowania istnieje luka, jest mało przekonujaccy ${ }^{42}$.

$$
* * *
$$

Należy przy tym pamiętać, że zasiedzenie jest pierwotnym sposobem nabycia prawa, co przy użytk. wiecz. prowadziłoby m.in. do wygaśnięcia zobowiązań wynikających z zawartej umowy, a więc jednej z podstaw prawnych określających treść prawa użyt. wiecz. Co więcej, prowadziłoby to do wygaśnięcia tej podstawy prawnej, która stanowi główne ograniczenie uprawnień użytkownika wieczystego w stosunku do uprawnień właściciela (co wynika z porównania treści art. 140 i $233 \mathrm{KC}$ ).

Istota pierwotnego charakteru nabycia wiąże się ściśle z brakiem kontynuacji praw i obowiązków pomiędzy poprzednikiem a następca prawnym, jak ma to miejsce w przypadku nabycia pochodnego. Nabywca prawa użytk. wiecz. $\mathrm{w}$ drodze zasiedzenia nie byłby zatem związany zobowiązaniami zaciagniętymi przez poprzedniego użytkownika. Uznanie poglądu Sądu Najwyższego za trafny wymagałoby zatem przyjęcia, obok pierwotnych skutków nabycia w sferze prawnorzeczowej, także ustawowego następstwa prawnego praw i obowiązków o charakterze obligacyjnym, wynikajacych z umowy o ustanowienie użytkowania wieczystego, czy też z decyzji ustanawiajacej warunki użytkowania wieczystego. Ilekroć jednak ustawodawca chce, aby doszło do kumulatywnego przystapienia do długu, zmiany dłużnika, zmiany wierzyciela, z mocy samego prawa (ex lege), czyni to w sposób wyraźny w przepisach prawa (np. art. $\left.55^{4}, 518 \mathrm{KC}\right)$.

Mnogość skutków prawnych, jakie zasiedzenie prawa użytkowania miałoby wywołać, a ponadto szeroki zakres modyfikacji norm prawnych, niezbędny dla dostosowania instytucji zasiedzenia do prawa użytkowania wieczystego, znacznie przekracza granice dopuszczalnej analogii, niezależnie od wcześniej zaprezentowanych argumentów dotyczących nieadekwatności instytucji zasiedzenia do prawa użytkowania wieczystego (brak możliwości posiadania prawa, pochodność użytkowania wieczystego).

$$
* * *
$$

Stanowisko Sądu Najwyższego wyrażone w uchwale z 11 grudnia 1975 r. o możliwości nabycia użytk. wiecz. w drodze zasiedzenia Bronisław Ziemianin określa jako stanowisko: „trafne i zasługujące w pełni na akceptację ${ }^{43}$.

\footnotetext{
${ }^{42}$ O tego rodzaju wadzie przy zasiedzeniu nieruchomości wspominaja: W. Koczara, A. Brzoza-Ostrowska, Zasiedzenie prawa użytkowania wieczystego w razie wad „decyzji uwłaszczeniowej”, „Nieruchomości” 2011, nr 7, s. 6, Legalis; E. Janeczko, op. cit., s. 54.

${ }^{43}$ B. Ziemianin, Prawo rzeczowe, Warszawa 2003, s. 141. Taki pogląd wyrazili także inni przedstawiciele doktryny, np. S. Wójcik, op. cit., s. 804; Z. Radwański, J. Panowicz-Lipska, „Nowe Prawo" 1979, nr 21, s. 80.
} 
Pogląd ten pozostaje raczej błędny, gdyż cytowane orzeczenie narusza cały szereg zasad obowiązujących we współczesnym prawie polskim, a zwłaszcza art. $172 \S 1 \mathrm{KC}$. Efektem zasiedzenia może być wyłącznie uzyskanie prawa własności, a nie użytk. wiecz. Przedmiotem zasiedzenia jest rzecz, a nie pra$\mathrm{wo}^{44}$. Zasiedzenia dokonuje nie posiadacz zależny, lecz posiadacz samoistny ${ }^{45}$. Przypisywanie użytkownikowi wieczystemu kwalifikacji „samoistnego posiadania prawa” albo „samoistnego posiadania nieruchomości” obraża treść cytowanego artykułu. Na powyższe zdaje się częściowo zwrócił uwagę Sąd Najwyższy w najnowszej uchwale składu siedmiu sędziów, w której w odpowiedzi na pytanie prawne składu trzyosobowego SN wskazano: „Samoistny posiadacz nieruchomości oddanej w użytkowanie wieczyste może nabyć jej własność przez zasiedzenie" ${ }^{\prime 6}$. Na dzień sporządzenia niniejszego artykułu nie jest znane jeszcze szczegółowe uzasadnienie uchwały, niemniej pogląd SN można częściowo odczytać z uzasadnienia samego pytania prawnego ${ }^{47}$. SN w uzasadnieniu pytania prawnego słusznie odwołał się m.in. do nieaktualności wykładni celowościowej dokonanej przez SN w wyżej cytowanej uchwale z 11 grudnia 1971 r., wykładni prokonstytucyjnej ochrony prawa własności. Szczególnie znamienny jest następujący fragment postanowienia - „Brak podstawy normatywnej do uznania każdej nieruchomości obciążonej prawem użytkowania wieczystego na rzecz osoby trzeciej za rzecz, co do której wyłączone jest posiadanie prowadzące do zasiedzenia prawa własności”.

Jak już wskazano we wcześniejszej części niniejszego artykułu, do tych samych wniosków można dojść już po samej analizie treści art. $172 \S 1 \mathrm{KC}$, istoty posiadania, i odwołania się do fundamentów instytucji zasiedzenia, funkcjonujących już w prawie rzymskim.

$$
* * *
$$

Biorąc pod uwagę to, co stwierdzono wyżej, należy podkreślić, iż brak podstaw prawnych do uznania dopuszczalności nabycia użytkowania wieczystego w drodze zasiedzenia. Do zasiedzenia niezbędne jest bowiem posiadanie samoistne rzeczy. Takie posiadanie przysługuje co do zasady właścicielowi i pozostaje przy właścicielu nawet przy oddaniu rzeczy w najem, dzierżawę, użytkowanie, użytkowanie wieczyste. Polskiemu prawu cywilnemu nie jest znane posiadanie prawa (wyjątek w tym zakresie - posiadanie służebności, wyraźnie

${ }^{44}$ J. Ciszewski, w: idem (red.), Kodeks cywilny. Komentarz, Warszawa 2014, s. 307; E. Gniewek, System prawa prywatnego, t. 3, Warszawa 2016, s. 85.

${ }^{45}$ Zob. na ten temat obszerny wywód G. Wolaka, op. cit., s. 814 i n. (przy wykorzystaniu wywodów J. Ignatowicza, S. Rudnickiego, K. Kruczalaka, T. A. Filipiaka, P. Machnikowskiego, op. cit., s. 814), a także postanowienia SN z 8 października 2008 r., V CSK 146/08, w którym czytamy: „samoistnym posiadaczem nieruchomości jest ten, kto włada nią jak właściciel (art. 136 $\mathrm{KC})$, korzystając z niej wyłączeniem innych osób, pobiera pożytki i dochody, a także uważa się za uprawnionego do rozporządzenia nią (art. $140 \mathrm{KC}$ ). Tych cech nie można przypisać tym, którzy władają nieruchomością w zakresie innego prawa, a więc także wieczystemu użytkownikowi”.

${ }^{46}$ Uchwała Składu Siedmiu Sędziów Sądu Najwyższego - Izba Cywilna z 9 grudnia 2016 r., III CZP 57/16, Biul. SN 2016, nr 12.

${ }^{47}$ Postanowienie SN z 6 kwietnia 2016 r., IV CSK 414/15, www.sn.pl. 
uregulowane ustawowo). Faktyczną formą władania nieruchomością na mocy użytkowania wieczystego jest posiadanie zależne, które jest niewystarczające do zasiedzenia.

Pogląd Sądu Najwyższego wyrażony po raz pierwszy w uchwale 7 sędziów z 11 grudnia 1971 r. razi swoją dowolnością i oderwaniem od konstrukcyjnych założeń instytucji zasiedzenia, co zaś w konsekwencji prowadzi do trudnych do zaakceptowania, daleko idących i niemajacych uzasadnienia w przepisach skutków prawnych takiego zasiedzenia. W tej sytuacji nastapić powinno wykreślenie z księgi zasad prawnych Sądu Najwyższego zasady ustalonej uchwałą 7 sędziów z 11 grudnia 1971 r. ${ }^{48}$

Instytucja zasiedzenia, wynaleziona i udoskonalona w prawie rzymskim, przejęta została do większości współczesnych systemów prawa. Do ustawodawstwa polskiego wprowadzona została po raz pierwszy dekretem o prawie rzeczowym z 11 października 1946 r. Dekret ten przewidywał, za kodeksem austriackim, nieznaną prawu rzymskiemu instytucję posiadania prawa, a także możliwość zasiedzenia ograniczonego prawa rzeczowego. Obie możliwości zarzucone zostały w obecnym polskim Kodeksie cywilnym. Jedyny wyjątek stanowi art. $352 \mathrm{KC}$ o posiadaniu służebności. Co się tyczy zasiedzenia, to jego przedmiotem może być tylko rzecz materialna znajdująca się w posiadaniu samoistnym dokonującego zasiedzenia. Tu znowu wyjątek stanowi art. 292 KC o zasiedzeniu służebności. W roku 1975 Sąd Najwyższy podją uchwałę o możliwości zasiedzenia użytkowania wieczystego. Sąd ten wyszedł z założenia, że w tym zakresie istnieje luka prawna, a skoro użytkowanie wieczyste jest podobne do prawa własności, można z tego tytułu zastosować analogię wobec użytkowania wieczystego. Obydwa poglądy SN uznać należy za błędne. Utratę użytkowania wieczystego przez długie jego nieużytkowanie przywrócić można z mocy kilku przepisów KC. Podobieństwa użytkowania wieczystego do prawa własności sa niewielkie. Przeprowadzając porównanie tych praw, zaledwie w sześciu przypadkach znaleziono ich podobieństwo, a w osiemnastu istnieją różnice. Nie ma tu także możliwości przyjęcia analogii z art. 292 KC. Stanowi on bowiem wyjątek, a w myśl już znanej prawu rzymskiemu, a także prawu polskiemu reguły: exceptiones non sunt extendendae. Na podstawie cytowanej uchwały SN w szeregu innych orzeczeń tego Sądu przyjęto koncepcję o istnieniu w prawie polskim możliwości posiadania prawa. Ponieważ w drodze analogii nie można kreować instytucji nieznanej w danym porządku prawnym, uznać należy, że SN, wprowadzając możliwość zasiedzenia prawa użytkowania wieczystego, dokonał tego, czego dokonać może wyłącznie ustawodawca.

prof. dr hab. Wtadystaw Rozwadowski

Emerytowany profesor Uniwersytetu im. Adama Mickiewicza

$w$ Poznaniu

${ }^{48}$ Cyt. na s. 77 i przyp. 25. 


\section{ACQUISITION OF THE PERPETUAL USUFRUCT RIGHT BY WAY OF PRESCRIPTION. CRITICAL REMARKS}

\section{Sum mary}

The institution of prescription was invented and perfected in Roman law, and was later incorporated into most modern legal systems. It was introduced into the Polish legislation by a decree on property law of 11 October 1946. Following the Austrian civil code, the decree provided for an institution unknown to Roman law, which was holding of a right, as well as a possibility of a prescription of a limited right in rem. Neither of the two rights has been included in the Civil Code currently in force in Poland. The only exception is its Article 352 which provides for an easement (servitude). As far as prescription is concerned, it may be only be applied to a thing in the autonomous possession of the owner. Again, Article 292 of the Civil Code providing for the prescription of an easement is an exception. In 1975, the Supreme Court passed a resolution on the inadmissibility of the prescription of perpetual usufruct rights. The court found that there is a legal loophole in this respect, and since perpetual usufruct is similar to ownership, an analogy can be applied to the former. Both views expressed by the Supreme Court are wrong. A perpetual usufruct lost in consequence of a long period of its non-use can be restored under several provisions of the Civil Code. However, the perpetual usufruct right and the ownership right are little similar to each other. A comparison of these rights shows similarities only in six, but differences in eighteen cases. Neither is it possible to adopt the analogy of Article 292 of the Civil Code. The provisions of this Article constitute an exception and according to the rule known under Roman law as well as Polish law: exceptiones non sunt extendendae. The above resolution of the Supreme Court had subsequently become the basis for later rulings and a number of other judgments have been delivered in which the court adopted a view of the existence under Polish law of the possibility of holding a right by prescription. However, since it is not possible to create an institution unknown in a given legal order simply by analogy, it ought to be considered that by introducing the possibility for the right to perpetual usufruct to prescribe, the Supreme Court has done what the legislator alone can do. 